ISSN 0103-5150

Fisioter. Mov., Curitiba, v. 30, n. 3, p. 493-500, Jul./Sep. 2017

Licenciado sob uma Licença Creative Commons

DOI: http://dx.doi.org/10.1590/1980-5918.030.003.A007

\title{
Physiotherapeutic approach and functional performance after breast cancer surgery
}

\author{
Abordagem fisioterapêutica e desempenho funcional \\ no pós-operatório de câncer de mama
}

\author{
Mariana Tirolli Rett, Íris Alves de Oliveira, Andreza Carvalho Rabelo Mendonça, \\ Camilla Benigno Biana, Ana Silvia Moccellin, Josimari Melo DeSantana*
}

Universidade Federal de Sergipe (UFS), São Cristóvão, SE, Brazil

\begin{abstract}
Introduction: Surgery for breast cancer can impair range of motion (ROM) and functionality of upper limb (UL). Objective: To compare ROM and functional performance of homolateral UL after physiotherapeutic approach and to correlate these variables. Methods: A non-randomized clinical trial study enrolled 33 women who were submitted to mastectomy or quadrantectomy associated with axillary lymphadenectomy. ROM was assessed by homolateral UL and contralateral limb (control) goniometry. Functional performance was assessed by "Disability of arm, shoulder and hand" (DASH) questionnaire. The protocol consisted in 10 sessions ( 3 sessions per week during 60 minutes), involving passive mobilization of glenohumeral and scapulothoracic joint, soft tissue mobilization, neck muscles and upper limb muscles stretching, exercises in all planes of motion, applied alone or in combination. Weight bearing exercise with elastic bands and dumbbells from 0.5 to 1.0 kilograms were also applied. Results: There was a meaningful increase in ROM of all movements after physiotherapy; however, flexion, abduction and lateral rotation remained lower than
\end{abstract}

\footnotetext{
MTR: PhD, e-mail: marianatrb@gmail.com

IA: BS, e-mail: irisalves@gmail.com

ACRM: MS, e-mail: andrezinharabelo@yahoo.com.br

CBB: undergrad, e-mail: camillacbb@gmail.com

ASM: PhD, e-mail: anamoccellin@ufs.br

JMS: PhD, e-mail: desantanajm@gmail.com
}

Fisioter Mov. 2017 Jul/Sep;30(3):493-500 
control limb. DASH score decreased significantly from $28.06 \pm 16.1$ to $15.71 \pm 10.7$ ( $p=0.001)$ meaning an improvement in functional performance of UL. No correlation was observed between ROM and DASH. Conclusion: Functional performance and ROM, after 10 physiotherapy sessions, improved significantly, however, a long-term follow-up can contribute to further improvement.

Keywords: Breast Neoplasms. Physical Therapy. Range of Motion. Mastectomy. Exercise Therapy.

\section{Resumo}

Introdução: A cirurgia para câncer de mama pode prejudicar a amplitude de movimento (ADM) e causar impacto negativo na funcionalidade do membro superior (MS). Objetivo: Comparar a ADM e desempenho funcional do MS homolateral à cirurgia após a abordagem fisioterapêutica, além de correlacionar estas variáveis. Métodos: Foi conduzido um ensaio clínico não randomizado, envolvendo 33 mulheres submetidas à mastectomia ou quadrantectomia associada à linfonodectomia axilar. A ADM foi avaliada pela goniometria do MS homolateral à cirurgia e do membro contralateral (controle). $O$ desempenho funcional foi avaliado pelo questionário "Deficiência do ombro, braço e mão" (DASH). Foram realizadas 10 sessões (3 sessões semanais com duração de 60 minutos), envolvendo mobilização passiva da articulação glenoumeral e escapulotorácica; mobilização cicatricial; alongamento da musculatura cervical e MMSS; exercícios ativos-livres em todos os planos de movimento, aplicados isoladamente ou combinados. Para os exercícios resistidos, utilizaram-se faixas elásticas e halteres de 0,5 a 1,0 kg. Resultados: Encontrou-se aumento significativo da ADM de todos os movimentos após a fisioterapia, mas a flexão, abdução e rotação lateral ainda estavam inferiores em relação ao membro controle. O escore total do DASH diminuiu significativamente de 28,06 $\pm 16,1$ para 15,71 $\pm 10,7$ $(p=0,001)$ indicando melhora do desempenho funcional do MS. Nenhuma correlação foi observada entre a ADM e o DASH. Conclusão: A realização de 10 sessões de fisioterapia melhorou a ADM e o desempenho funcional do MS homolateral à cirurgia, mas acompanhamentos em um prazo mais longo podem contribuir para ganhos adicionais.

Palavras-chave: Neoplasias da Mama. Amplitude de Movimento Articular. Fisioterapia. Mastectomia. Terapia por Exercício.

\section{Introduction}

The breast cancer is the most common type of cancer among women and the second most frequent cancer in the world (1). Even with diagnostic and treatment evolution like the availability of sentinel lymph node (SLN) procedure, surgical techniques are also prevalent (2). The most common surgeries are lumpectomy, quadrantectomy and mastectomy that may be associated to axillary lymphadenectomy (AL) (3 - 5). In addition, complementary therapies neoadjuvant or adjuvant as chemotherapy (CT), radiotherapy (RT) and hormonotherapy (HT) may be used.

Besides the range of motion (ROM) depletion another complications may appeared after the surgery procedure as scar retractions, fibrosis, seroma, lymphedema, muscular weakness, pain, postural deviations and intercostobrachial nerve paresthesia (3 - 12). ROM limitation is the most common complication after surgery and affects more than half of women both in immediate and late postoperative (6, 13). ROM limitation may also cause a negative impact on upper limber (UL) function affecting quality of life (QOL) $(14,15)$. The impact on upper limb function is related to frequent complaints as difficulty to perform work, domestic and daily life activities $(5,8,9,12,16)$.

In this context, physiotherapy approach plays a fundamental role in the rehabilitation after breast cancer surgery, acting in functional recovering, preventing complications, and enhancing QOL of these women (17). As a result, physiotherapy might contribute to a rapidly reintegration to occupational and life activities and consequently to society, avoiding function limitation (18-22). Therefore, the knowledge of women functional performance after breast 
cancer surgery enables healthcare professionals, especially physiotherapists, to collect useful information that will help them to develop treatment strategies both preventive and therapeutic.

Thus, the aims of this study were to compare articular range of motion (ROM) and functional performance of homolateral UL submitted to surgery after physiotherapeutic approach and to correlate these variables.

\section{Methods}

The study was a non-randomized clinical trial that included women who were submitted to mastectomy or quadrantectomy associated to AL of three levels and received physiotherapeutic treatment at Physiotherapy Department of OncoHematos at Foundation of Beneficence of Cirurgia Hospital in Aracaju, Sergipe. This study followed the guidelines of National Health Council and the rules of 466/12 Resolution about biomedical research involved humans, with approval of Review Board of Federal University of Sergipe (UFS) (number 39816, CAAE 02201312.2.20000.0058). Participants have assigned informed consent.

Exclusion criteria of this study were women without shoulder ROM limitation (23), those were submitted to bilateral mastectomy and immediate or late mammary reconstruction, women with active infection process, previous dysfunction of homolateral UL to surgery, difference of length of 4 centimeters or more between upper limbs, previous history of physiotherapy treatment and incapacity of questionnaires comprehension.

First, personal data as age, height, weight, occupation, scholarity level and marital status, also clinical and surgical data as type, side and time of post-surgical, complementary treatments, and number of dissected and compromised lymph nodes both were collected on clinical record available in local. Second, at physical examination, ROM of homolateral UL after surgery and contralateral UL after surgery, which was considered control limb, were evaluated by goniometry measurement. The goniometer used was from $\mathrm{Carci}^{\circledR}$ brand and was comprised by a circular plastic that ranges from $0^{\circ}$ to $360^{\circ}$ degrees and have two plastic moveable arms. The movements measured were flexion, extension, abduction, adution, medial (MR) and lateral rotation (LR) (23) of both homolateral and contralateral shoulders to surgery. Values were registered in degrees and measurements were repeated three times, the average was adopted.

Functional performance was evaluated by "Disability of shoulder, arm and hand" questionnaire (DASH) (24), which comprises upper limb as a whole. Dash is composed by 30 questions that evaluate physical function and symptoms. Its items are about difficulty in performing physical activities; severity of each symptoms as pain, tingling, weakness, and stiffness; and the problems effect on social activities, work, and sleep, and its psychologic impact. DASH score is based in a scale from 0 to 5 points and raw score ranges from 0 (without disability) to 100 (several disability). In this study the optional modules to athletes/ musicians/ workers were not applied because do not match with the patient's profile evaluated.

The physiotherapy protocol consisted in 10 sessions, distributed in 3 sessions of 60 minutes weekly and is described on Table 1.

Table 1 - Physiotherapy Protocol

\begin{tabular}{|c|c|}
\hline $\begin{array}{l}\text { Physiotherapy Protocol - } 10 \text { sessions } \\
\text { ( } 3 \text { sessions per week with } 60 \mathrm{~min} \\
\text { each one) }\end{array}$ & Parameters \\
\hline $\begin{array}{l}\text { Glenohumeral and scapulothoracic } \\
\text { passive mobilization }\end{array}$ & 3 sets of 60 seconds \\
\hline Soft tissue mobilization & \\
\hline $\begin{array}{l}\text { Passive stretching of upper limbs } \\
\text { muscles and neck muscles }\end{array}$ & $\begin{array}{l}1 \text { set of } 30 \text { to } 60 \\
\text { seconds }\end{array}$ \\
\hline $\begin{array}{l}\text { Free active exercises to flexion, } \\
\text { extension, abduction, aduction, lateral } \\
\text { and medial rotation movements }\end{array}$ & $\begin{array}{l}3 \text { sets of } 8 \text { to } 12 \\
\text { repetitions }\end{array}$ \\
\hline $\begin{array}{l}\text { Free active exercises to different } \\
\text { muscular groups in all planes of } \\
\text { motion and combination planes }\end{array}$ & $\begin{array}{l}3 \text { sets of } 8 \text { to } 12 \\
\text { repetitions }\end{array}$ \\
\hline $\begin{array}{l}\text { Weight-bearing exercises using elastic } \\
\text { band or dumbbells from } 0,5 \text { to } 1,0 \mathrm{~kg} \\
\text { according to patient evolution }\end{array}$ & $\begin{array}{l}3 \text { sets of } 8 \text { to } 12 \\
\text { repetitions }\end{array}$ \\
\hline $\begin{array}{l}\text { Recommendations about arm } \\
\text { management as general care and skin } \\
\text { care }\end{array}$ & Daily \\
\hline
\end{tabular}

One investigator applied goniometry measurement and DASH questionnaire before and after the performance of physiotherapy sessions, while another independent investigator applied the physiotherapy protocol. Data were analyzed by BioEstat 5.0 and included descriptive analysis, measurement of central 
tendency (average), dispersion (standard deviation), relative and absolute frequency. Follow normality of data, to compare DASH scores and ROM before and after 10 session was used $t$ - Student dependent test. To compare ROM homolateral and contralateral was used t-Student independent test. To correlate DASH and ROM variables was used Pearson correlation test. The significance level was $\mathrm{p}<0.05$ for all analyses.

\section{Results}

The study select 39 patients, those 33 matched with inclusions criteria. During the study 2 patients dropped out of treatment, 2 did not comprehend the questionnaires and 1 died before the study ending. The personal and clinical-surgical characteristics are described on Table 2.

Table 2 - Sample clinical and surgery characteristics $(n=33)$

\begin{tabular}{|c|c|c|}
\hline \multicolumn{3}{|c|}{ Personal and surgical characteristics } \\
\hline Age (years) & & $50.9 \pm 10.8$ \\
\hline Body mass index (kg/m²) & & $26.3 \pm 5.2$ \\
\hline \multirow[t]{3}{*}{ Marital status } & single & $11(33)$ \\
\hline & married & $15(46)$ \\
\hline & widow & $7(21)$ \\
\hline \multirow[t]{3}{*}{ Skin color } & brown & $16(49)$ \\
\hline & black & $10(30)$ \\
\hline & white & $7(21)$ \\
\hline \multirow[t]{3}{*}{ Occupation } & housewife & $14(43)$ \\
\hline & farmer & $6(18)$ \\
\hline & others (e.g.: teacher, seller) & $13(39)$ \\
\hline \multirow[t]{2}{*}{ Surgery type } & mastectomy & $26(78.9)$ \\
\hline & quadrantectomy & $7(21.3)$ \\
\hline \multirow[t]{2}{*}{ Surgery side } & right & $14(42.4)$ \\
\hline & left & $19(57.6)$ \\
\hline \multirow[t]{3}{*}{ Post-surgical time } & among 4 weeks ( 1 month) & $8(24.3)$ \\
\hline & between 4 and 8 weeks (1-2 months) & $17(51.5)$ \\
\hline & after 8 weeks & $8(24.3)$ \\
\hline \multirow[t]{2}{*}{ Radiotherapy } & adjuvant & $11(35.5)$ \\
\hline & neoadjuvant & $1(3.2)$ \\
\hline \multirow[t]{2}{*}{ Chemotherapy } & adjuvant & $24(82.7)$ \\
\hline & neoadjuvant & $9(31.0)$ \\
\hline Hormonotherapy & & $10(32.2)$ \\
\hline Dissected lymph nodes & & $14.0 \pm 6.8$ \\
\hline Compromised lymph nodes & & $3.4 \pm 4.1$ \\
\hline
\end{tabular}

Note: Average values \pm standard deviation; $n(\%) ; \mathrm{kg}=$ kilogram; $\mathrm{m}=$ meter.

The ROM values of all movements are significantly lower in homolateral UL to surgery compared to contralateral UL as seen on Table 3, demonstrating the ROM limitation at physiotherapy admission. After 10 sessions of physiotherapy, ROM of homolateral UL increased significantly in all movements, demonstrating an important improvement. However, in compare to control UL, the movements of flexion, abduction and lateral rotation remained lower. 
Table 3 - Comparison of range of motion (ROM) after lst and 10th session of physiotherapy $(\mathrm{n}=33)$

\begin{tabular}{|c|c|c|c|c|c|c|}
\hline \multirow{2}{*}{ ROM } & \multirow{2}{*}{$\begin{array}{c}\text { Contralateral UL } \\
\text { (control) }\end{array}$} & \multicolumn{2}{|c|}{ Homolateral UL } & \multirow{2}{*}{$\mathrm{pl}^{*}$} & \multirow{2}{*}{$\mathrm{p} 2^{\star}$} & \multirow{2}{*}{$\mathrm{p} 3 * *$} \\
\hline & & $1^{\text {st }}$ session & $10^{\text {th }}$ session & & & \\
\hline Flexion & $161.3 \pm 19.8$ & $110.1 \pm 35,6$ & $143.9 \pm 24.1$ & 0.001 & 0.002 & 0.001 \\
\hline Extension & $61.2 \pm 14$ & $51.8 \pm 13.1$ & $59.3 \pm 10.3$ & 0.007 & 0.551 & 0.001 \\
\hline Abdction & $156.9 \pm 23.4$ & $112.9 \pm 30.8$ & $140.8 \pm 26.4$ & 0.001 & 0.010 & 0.001 \\
\hline Aduction & $42.9 \pm 12.3$ & $33.2 \pm 12.1$ & $40.3 \pm 10.8$ & 0.002 & 0.371 & 0.001 \\
\hline MR & $81.9 \pm 11.3$ & $75.3 \pm 15.5$ & $82.0 \pm 8.4$ & 0.027 & 0.970 & 0.006 \\
\hline LR & $84.4 \pm 8.8$ & $65.1 \pm 23.7$ & $74.6 \pm 17.9$ & 0.001 & 0.007 & 0.001 \\
\hline
\end{tabular}

Note: Average values ( \pm standard deviation); $M R=$ medial rotation, $L R=$ lateral rotation; $p 1$ : contralateral UL $x$ homolateral UL 1st session; p2: contralateral UL x homolateral UL10th session; p3: homolateral UL 1st session $x$ homolateral UL 10th session; * $\mathrm{t}$ - Student dependent test; **t- Student independent test.

DASH score reduced significantly from $28.06 \pm$ 16.1 to $15.71 \pm 10.7$ ( $\mathrm{p}=0.001)$, concluding improvement of functional performance of homolateral UL to surgery (Figure 1).
In addition, no meaningful correlation between ROM and DASH was found, except a weak and negative one about extension movement and total score of DASH after 10 sessions (Table 4).

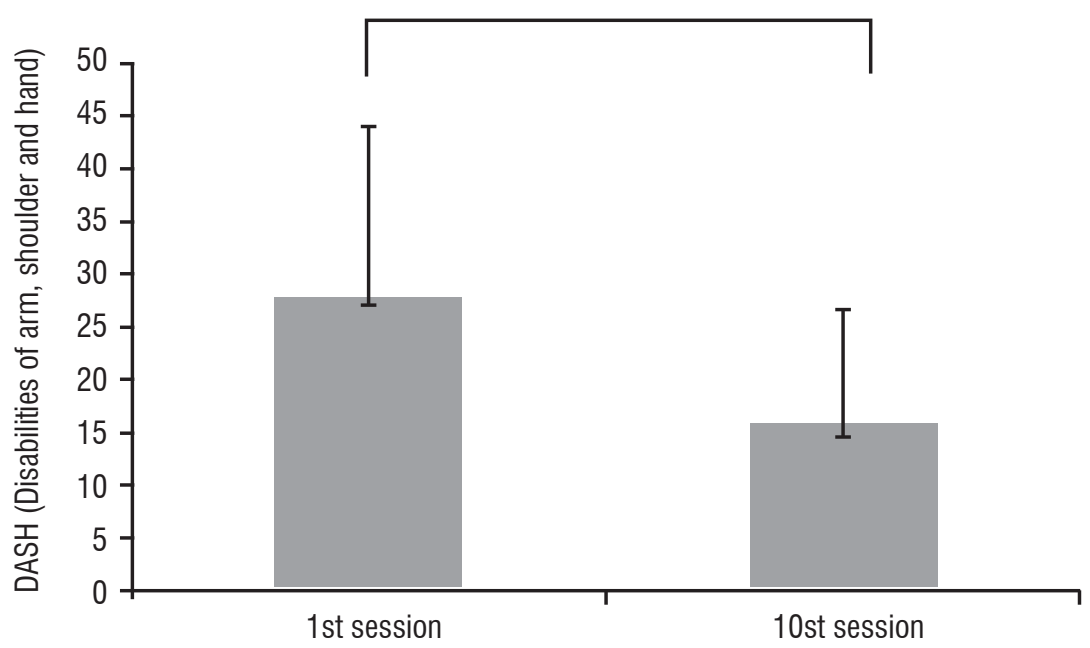

Figure 1 - Comparison of DASH score after lst session and 10th session of physiotherapy $(n=33)$; ${ }^{\star} p=0,001$; T- Student test.

Table 4 - Correlation between DASH score and ROM of homolateral UL to surgery at 1st session and 10th session of physiotherapy

\begin{tabular}{lcccc}
\hline & \multicolumn{2}{c}{ DASH } & \multicolumn{2}{c}{$\mathbf{1 0}^{\text {st }}$ session } \\
\multicolumn{1}{c}{ ROM } & \multicolumn{1}{c}{ session } \\
\hline Flexion & -0.2648 & 0.1363 & $r$ & $p$ \\
Extension & -0.1786 & 0.3199 & -0.2944 & 0.0962 \\
Abduction & -0.125 & -0.4339 & 0.0116 \\
Aduction & -0.2648 & 0.4883 & -0.2223 & 0.2137 \\
MR & 0.1034 & 0.1364 & -0.3011 & 0.0886 \\
LR & -0.011 & 0.5673 & -0.2204 & 0.2176 \\
\hline
\end{tabular}

Note: $M R=$ medial rotation, $L R=$ lateral rotation; $r=$ Pearson correlation, $p<0,05$. 


\section{Discussion}

Before sessions of physiotherapy, at first evaluation, ROM of homolateral UL was lower than control, besides DASH score was elevated what indicated a damage in functional performance. Clinically, this finds are common in most of women submitted to mastectomy. They occur due to surgical scar dimension, to AL, and to both presence of pain and fear of moving the arm $(3-5,7,8,26)$. This affirmation may be confirmed by the answers to DASH questionnaire at our study, where most patients answer: "very difficult to do" or "unable to do" to questions about "place an object on a shelf above your head", "wash your backs" and "carry a heavy object". An study of Rietman et al. (7) found evidences that $20 \%$ of women referred difficult to pull a sweater overhead, $18 \%$ to fasten a bra, $72 \%$ to do up back zipper, $16 \%$ to reach overhead and $29 \%$ to carry heavy bag in immediate post-surgical, that corroborate with our study.

Nowadays, the SLN procedure brings less complications and morbidity after surgery $(4,5)$ than AL technique, as confirmed to Velloso et al. (5), that found a lower impairment in ROM and DASH scores in 45 patients submitted to SLN procedure. Despite of these finds, all of women in our study were submitted to AL technique, what may justify ROM reduction and impair of functional performance after surgery.

It is a consensus that early rehabilitation after breast cancer is highly recommended since promote an adequate functional recovery (21, 27 - 29). Unfortunately, in our study a small number of women begun rehabilitation before 4 weeks post-surgical, though, the women recovered ROM and enhanced functionality. Similarly, Lauridsen et al. (10) randomized 139 women in two groups to rehabilitation, group one received treatment before eight weeks post-surgical and group 2 after 26 weeks post-surgical, and they found improvement of functions in both groups. An earlier approach in our study was difficulty due to the outset of physiotherapy to women in post-surgical period depends of public transportation availability and this physiotherapy service is the unique of public health system (SUS) available in the State.

It is also a consensus that kinesiotherapy is the first choice to rehabilitation after breast cancer surgery, and it is also indispensable to preventing and treating physical and functional impairments after surgery (18 - 22). Randomized controlled trials have demonstrated an important improvement of shoulder functional capacity after practice of active free ROM exercises. However, there is no consensus about the number of sessions necessaries to restore ROM and functionality $(18,20$ - 22).

In our study, 10 sessions of physiotherapy resulted in significant improvement of ROM and reduction of DASH score, leading to enhancement of functional performance $(27,30)$. The patient's complaint had an intensity reduction. Some patients reported no more difficulty to perform tasks as "washing your back, putting on a sweater, preparing a meal, enjoying recreational activities, making a bed, carrying heavy objects, washing and drying your hair". As well, patients reported less symptoms as pain, weakness, and difficult to move arm, shoulder and hand.

Nevertheless, 10 sessions could not be sufficient to entire returning to activities and entire enhancement of clinical-functional impairments in post-operative of breast cancer, since that remained a deficit in movements as flexion, abduction and lateral rotation in compare to control limb. Thus, the literature believes that a long-term follow-up could help in additional improvement of ROM and functionality (20, 28, 29).

The women who depends of public health system (SUS) or even those with private health plans could face different realities of follow-up after surgery, many times with a limited number of physiotherapy sessions with a specialist. Therefore, physiotherapists should offer a good treatment to achieve satisfactory results even in a short time frame. As suggestion, exercises with movements of flexion, abduction and lateral rotation should be emphasized.

No meaningful correlation between ROM and DASH was found, except a weak and negative one about extension movement and total score of DASH after 10 sessions. Clinically, this is an irrelevant result, since the movement of extension is barely impaired in these patients. Conversely, Thomas-Maclean (12) in an study with 357 women that evaluated ROM, pain, lymphedema and this variables correlation with DASH, 6 and 12 months after surgery, observed a meaningful correlation of ROM limitation and pain with functional performance. Although no correlation between these variables in our sample size was found, the women in our study have a better performance and few limitations to execute daily life activities.

In Brazil, 57.960 new cases of breast cancer are estimated per year, thus many women will be submitted 
to surgery and complementary treatments that may result in impairments, demonstrating the importance of this study and its results (1). Furthermore, women after breast cancer surgery have led a more active lifestyle with more QOL, demonstrating the importance of functional recovery of UL to perform work, domestic and daily life activities. Evaluation of ROM and functional performance in clinical practice is an important tool to develop strategies and actions of prevention and treatment of physical and functional impairments caused by breast cancer treatment.

Presence of a control group was not possible in this study due to local routine, which all patients are admitted and referral to physiotherapy, avoiding a delay in treatment that may prejudice functional recovery. Thereby, contralateral UL was adopted as a control measurement to compare ROM, but it is unable to be a DASH control. No long-term results can be obtained, as patients were evaluated after 10 sessions of physiotherapy. ROM and functional performance improve after physiotherapy; however, abduction, lateral rotation and flexion exercises should be intensified.

Studies with a long-term follow-up and a greater sample size may offer more information to health professionals involved with breast cancer rehabilitation, as well, to oncologic services and mainly to these women.

\section{Conclusion}

Ten sessions of physiotherapy improve ROM and functional performance of homolateral UL to surgery; however, no correlation was found between these variables. A long-term follow-up may corroborate to additional improvement.

\section{Acknowledgment}

To patients, to OncoHematos service of Fundação Beneficência Hospital de Cirurgia, to Programa Institucional de Bolsas de Iniciação Científica (PIBIC/ UFS) and CNPq.

\section{References}

1. Brasil. Instituto Nacional de Câncer (INCA). Estimativas 2016: incidência de câncer no Brasil. 2016 [cited 2016 Feb 1]. Available from: http://tinyurl.com/pnpjme4.
2. Ferlay J, Shin HR, Bray F, Forman D, Mathers C, Parkin DM. Estimates of worldwide burden of cancer in 2008: GLOBOCAN 2008. Int J Cancer. 2010;127(12):2893-917.

3. Ewertz M, Jensen AB. Late effects of breast cancer treatment and potentials for rehabilitation. Acta Oncol. 2011;50(2):187-193.

4. Del Bianco P, Zavagno G, Burelli P, Scalso G, Barutta L, Carraro P, et al. Morbidity comparison of sentinel lymph node biopsy versus conventional axillary lymph node dissection for breast cancer patients: results of the sentinella-givom Italian randomized clinical trial. Eur J Surg Oncol. 2008;34(5):508-13.

5. Velloso FS, Barra AA, Dias RC. Function performance of upper limb and quality of life after sentinel lymph node biopsy of breast cancer. Rev Bras Fisioter. 2010;15(2):146-53.

6. Stubblefield MD, Keole N. Upper body pain and functional disorders in patients with breast cancer. PM R. 2014;6(2):170-83.

7. Rietman JS, Dijkstra PU, Hoekstra HJ, et al. Late morbidity after treatment of breast cancer in relation to daily activities and quality of life: a systematic review. Eur J Surg Oncol. 2003;29(3):229-38.

8. Nesvold IL, Fossa SD, Holm I, Naume B, Dahl AA. Arm shoulder problems in breast cancer survivors are associated with reduced health and poorer physical quality of life. Acta Oncol. 2010;49(3):347-53.

9. Bezerra TS, Rett MT, Mendonça ACR, Santos DE, Prado VM, Santana JM. Hypoesthesia, pain and disability of upper limb after adjuvant radiotherapy for breast cancer. Rev Dor. 2012;13(4):320-6.

10. Lauridsen MC, Overgaard M, Overgaard J, Hessov IB, Cristiansen P. Shoulder disability and late symptoms following surgery for early breast cancer. Acta Oncol. 2008;47(4):569-75.

11. Gouveia PF, Gonzalez EO, Grer PA, Fernandes CA, Lima MC. Avaliação da amplitude de movimento e força da cintura escapular em pacientes de pós-operatório tardio de mastectomia radical modificada. Fisioter Pesq. 2008;15(2):172-6.

12. Thomas-Maclean RL, Hack T, Kwan W, Towers A, Miedema B, Tilley A. Arm morbidity and disability after breast cancer: new directions for care. Oncol Nurs Forum. 2008;35(1):65-71. 
13. Hayes SC, Johansson K, Stout NL, Prosnitz R, Armer JM, Gabram S, et al. Upper-body morbidity after breast cancer: incidence and evidence for evaluation, prevention, and management within a prospective surveillance model of care. Cancer. 2012;118(8 Suppl):2237-49.

14. Ebaugh D, Spinelli B, Schmitz KH. Shoulder impairments and their association with symptomatic rotator cuff disease in breast cancer survivors. Med Hypotheses. 2011;77(4):481-7.

15. Rett MT, Mendonça ACR, Santos RM, Jesus GKS, Prado VM, Santana JM. Fisioterapia no pós-operatório de câncer de mama: um enfoque na qualidade de vida. ConsSaude. 2013;12(3):392-397.

16. Nyssen SM, Correia GN, Garcia APU, Driusso P. Capacidade funcional e qualidade de vida em mulheres pós-mastectomizadas. Rev Bras Cancerol. 2010;56(4):423-30.

17. Groef AD, Van Kampen M, Dieltjens E, Christiaens MR, Neven P, Geraerts I, et al. Effectiveness of postoperative physical therapy for upper-limb impairments after breast cancer treatment: a systematic review. Arch Phys Med Rehabil. 2015;96(6):1140-53.

18. Lauridsen MC, Christiansen P, Hessov I. The effect of physiotherapy on shoulder function in patients treated surgically for breast cancer: a randomized study. Acta Oncol. 2005;44(5):449-57.

19. Rett MT, Mesquita PJ, Mendonça ARC, Moura DP, DeSantana JM. Kinesiotherapy decreases upper limb pain in females submitted to mastectomy or quadrantectomy. Rev Dor. 2012;13(3):201-7.

20. Beurskens CHG, Uden CJT, Strobbe LJA, Oostendorp RAB, Wobbes T. The efficacy of physiotherapy upon shoulder function following axillary dissection in breast cancer, a randomized controlled study. BMC Cancer. 2007;7:166.

21. Silva MPP, Derchain SFM, Rezende L. Movimento do ombro após cirurgia por carcinoma invasor da mama: estudo randomizado prospectivo controlado de exercícios livres versus limitados a $90^{\circ}$ no pós-operatório. Rev Bras Ginecol Obstet. 2004;26(2):125-30.

22. Oliveira MMF, Gurgel MSC, Miranda MS, Okubo MA, Feijó LFA, Souza GA. Efficacy of shoulder exercises on locoregional complications in women undergoing radiotherapy for breast cancer: clinical trial. Rev Bras Fisioter. 2009;13(2):136-43.
23. Marques AP. Manual de goniometria. São Paulo: Manole; 1997.

24. Orfale AG, Araújo PMP, Ferraz MB, Natuor J. Translation into brazilian portuguese, cultural adaptation and evaluation of the reliability of the disabilities of the arm, shoulder and hand questionnaire. Braz J Med Biol Res. 2005;38(2):293-302.

25. Chung C, Lee S, Hwang S, Park E. Systematic review of exercise effects on health outcomes in women with breast cancer. Asian Nurs Res (Korean Soc Nurs Sci). 2013;7(3):149-59.

26. Silva MD, Rett MT, Mendonça ACR, Silva Jr WM, Prado VM, Santana JM. Qualidade de Vida e Movimento do Ombro no Pós-Operatório de Câncer de Mama: um Enfoque da Fisioterapia. Rev Bras Cancerol. 2013;59(3):419-26.

27. Campanholi LL, Góes JA, Alves LBG, Nunes LCBG. Análise goniométrica no pré e pós- operatório de mastectomia com aplicação de protocolo fisioterapêutico. RUBS. 2006;2(1):14-23.

28. Scaffidi M, Vulpiani MC, Vetrano M, Conforti F, Marchetti MR, Bonifacino A, et al. Early rehabilitation reduces the onset of complications in the upper limb following breast cancer surgery. Eur J Phys Rehabil Med. 2012;48(4):601-11.

29. Sanchez MJY, Lacomba MT, Sanchez BS, Merino DP, Costa SP, Tellez EC, et al. Health related quality of life improvement in breast cancer patients: secondary outcome from a simple blinded, randomised clinical trial. Breast. 2015;24(1):75-81.

30. 30. Rett MT, Santos AKG, Mendonça ACR, Oliveira IA, Santana JM. Efeito da fisioterapia no desempenho funcional do membro superior no pós-operatório de câncer de mama. Ciênc Saúde (Porto Alegre). 2013;6(1):18-24.
Received in 06/12/2014

Recebido em 12/06/2014

Approved in 11/16/2016

Aprovado em 16/11/2016 